\title{
Comparative Politics
}

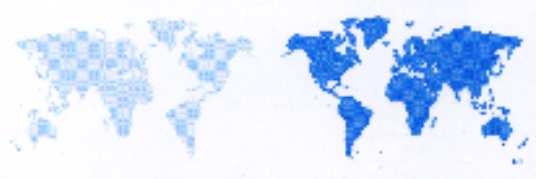

The Anatomy of the Turkish Military's Political Autonomy

Author(s): Ümit Cizre Sakallioğlu

Source: Comparative Politics, Vol. 29, No. 2 (Jan., 1997), pp. 151-166

Published by: Comparative Politics, Ph.D. Programs in Political Science, City University of New York

Stable URL: https://www.jstor.org/stable/422077

Accessed: 31-01-2019 14:30 UTC

\section{REFERENCES}

Linked references are available on JSTOR for this article:

https://www.jstor.org/stable/422077?seq=1\&cid=pdf-reference\#references_tab_contents You may need to log in to JSTOR to access the linked references.

JSTOR is a not-for-profit service that helps scholars, researchers, and students discover, use, and build upon a wide range of content in a trusted digital archive. We use information technology and tools to increase productivity and facilitate new forms of scholarship. For more information about JSTOR, please contact support@jstor.org.

Your use of the JSTOR archive indicates your acceptance of the Terms \& Conditions of Use, available at https://about.jstor.org/terms

Comparative Politics, Ph.D. Programs in Political Science, City University of New York is collaborating with JSTOR to digitize, preserve and extend access to Comparative Politics 


\title{
The Anatomy of the Turkish Military's Political Autonomy
}

\author{
Ümit Cizre Sakallioğlu
}

The most profound contradiction marking Turkish democracy in the 1990s is the demonstrated inability of civilian politicians to control the military. The Turkish military enjoys a strong degree of military autonomy. Three times it has intervened in Turkish politics.

The patterned nature of military-civilian relations has created a legacy that reinforces and maintains the independence of the armed forces. Since 1980, however, fresh developments make studying military-civilian relations even more significant. First, the democratic thrust of the radically altered political economy since 1980, both domestically and internationally, must be considered. The growing political role of the armed forces is at best anachronistic and at worse incongruent with the regime's commitment to the norms associated with liberal democracy and free market capitalism. The existence of parallel state structures, one civilian and the other military, undermines the authority and the democratic accountability of elected civilian governments. Furthermore, despite the deep breach in Turkish politics between rhetoric and action, the structural distortions and contradictions generated by the march toward a more "liberal" economic and political order, and the Kurdish insurgency, one should not assume that the past necessarily predicts the future. Finally, there are internal and global conditions antagonistic to the military's ethics and political credentials. Nevertheless, the harmony of the series of civilian governments with the military since the transition to civilian democracy testifies to the civilians' tenuous hegemony.

This essay addresses the current difficulty in reasserting civilian supremacy in the Turkish political system. The problem will be identified and analyzed by focusing on several theoretical points, from a historical perspective, relating to the substance and sources of the Turkish military's autonomy. The autonomy of the military will then be examined using index variables measuring the military's political effectiveness vis-à-vis civilian institutions over the last two decades. It is important to note that this essay neither analyzes the causes of coups in Turkey nor studies the nature and consequences of the transition from military to civilian rule. Rather, it focuses on the expanded role of the Turkish military under civilian governments since the 1980 coup. 


\section{Theoretical Notes on the Substance of the Political Autonomy of the Turkish Military}

Military autonomy can be analyzed on two levels: one, institutional autonomy, corresponding to structural properties, and the other, political autonomy, pertaining to political goals and influences.' The former embodies a defensive goal: "the military guards its core professional functions against unwanted interference by outsiders." The latter involves both an ideological and a behavioral dimension; the political autonomy of the military is an offensive strategy transcending institutional boundaries and representing "the military's aversion toward, or even defiance of, civilian control." 3

The military's institutional raison d'être is to preserve its integrity, unity, and modernity. This general goal, which can be subsumed under the rubric of institutional autonomy, can be fulfilled only if the military exercises its power to make decisions regarding four areas: promotions, appointments, and punishments of junior personnel; levels in the armed forces; military education and doctrine; and military reform and modernization. Theoretically, perhaps the most controversial component of institutional autonomy is professionalism as part of military education and reform. Aside from the debate about the old versus the new professionalism, ${ }^{4}$ the overwhelming evidence from the Middle East and Latin America suggests that a quantitative and qualitative increase in professional skills under the impact of cold war internal security concerns has increased the military's influence in political as well as purely defense matters. ${ }^{5}$ Since most Third World militaries are presently concerned primarily with internal insurgencies caused by rising ethnic and nationalist aspirations, it seems likely that in the future they will be even more interested in politics and in influencing government than they were when Communism was considered as much an internal as an external threat. ${ }^{6}$

It is natural for any military to have professional independence and to make its own internal decisions. What is at issue here, however, is the possibility that this defensive-sounding goal of "protecting its self-governing autonomy" will be turned into an instrument for "limiting the government's prerogatives by strengthening the military's own decision-making powers."7 Professionalization and modernization are assumed to help the military refuse to relegate itself to a subordinate position within the civilian constitutional order. Indeed, in the 1980 takeover the Turkish military acted more cohesively and hierarchically than previously. However, neither professionalism nor the need to protect the other four requisites of corporate autonomy can provide the critical impetus for the military to expand its political role because, in most cases, organizational strength is a function of the scope and structure of political strength/autonomy which calls into question the historical-cultural context from which the military's political power 
arises. It is thus meaningful to consider some subtle dimensions of the Turkish military's political autonomy.

The political autonomy of the military, which has been defined as its ability to go above and beyond the constitutional authority of democratically elected governments, can include not only direct but also indirect influences on the government. ${ }^{8}$ The model of interaction between civilian governments and the military in Turkey, from the transition to competitive democracy in 1983, provides evidence of indirect influence. Since 1983 the military has used legal/ constitutional, historical/cultural, and structural reasons and mechanisms to retain its privileged position in issuing demands, policy suggestions, and warnings on political matters. It has done so at the expense of nonmilitary groups, such as the left, youth, the retired, women, the unemployed, and intellectuals, whose views carry less weight. This privileged position of the military forms the core of the Turkish military's political prerogatives.

The most crucial feature of the Turkish military's political autonomy, which in turn distinguishes it from armies elsewhere in the Third World, is its acceptance of the legitimacy of both democracy and civilian rule. It has adopted a refined concept of autonomy by which it controls politicians according to its own ideas and maxims. It is not praetorian; it has not tried to undermine democracy or usurp civilian authority. The Turkish military has not destroyed civilian-military boundaries; "'military government,' in the sense of serving officers wielding executive and legislative power directly, [has been] something alien to them." 9 Instead, it has asserted its political effectiveness mostly "through the medium of the army rather than by infiltrating civilian institutions," which has left "integral boundaries between civil and military institutions . . . much more intact than in Thailand and Indonesia." 10 Indeed, in these Southeast Asian countries the military has been viewed "as a political machine, with many senior military officers functioning as "military politicos" "holding cabinet and bureaucratic positions." The Turkish armed forces, in contrast, refrain from this form of direct involvement, which they consider to be against their understanding of democracy and lethal to their professional cohesion. They choose to wield influence in the structuring and vetoing of political initiatives from a position outside the civilian authorities' constitutional control.

The impermeability of civilian-military boundaries in Turkey has had two primary political implications. First, the military's acceptance of the civilian regime's legitimacy and staying power has required it to use unobtrusive mechanisms to disguise its political weight. One significant method is its application of the constitutional powers accorded to the military after each past intervention. ${ }^{12}$ While extensively restricting individual rights and freedoms, the latest constitution of 1982 entrenched the military's veto power in the political 
system to such an extent that it has made crude military intervention into politics redundant.

Second, the Turkish army's autonomous, behind-the-scenes power seems to be above politics and to be supranational. In other words, the ultimate justification for the military's political predominance rests on its "guardianship of the national interest," of which maintaining national unity is considered to be the most important component. Therefore, it becomes imperative to question the nature of the military's autonomy as a reflection of and response to broader social cleavages, both economic and social.

It has sometimes been argued that the Turkish army tends to act as the defender of middle class interests and in turn of the capitalist market economy through the integration of its top echelons into the existing capitalist order. ${ }^{13}$ Not surprisingly, proponents of this perspective have tried to establish the identity and nature of civilian support for the military's political role in Turkey in terms of the social classes most likely to support it. ${ }^{14}$

Social cleavages traditionally provide a good explanation of civilian-military relations in any society. However, together with the civilian bureaucrats, the Turkish army historically built the republic and subsequently modernized it along a western path. This mission turned it into the political symbol of nationhood and the instrument of preserving the nation. Because of the republic's obsessive anxiety in maintaining national unity in the face of divisive forces, such as Islam, sectarianism, and separatist Kurdish nationalism, the Turkish army has really not taken openly partisan positions. Similar to those Brazilian officers from the middle class who perceived themselves as classless soldiers promoting the national interest, the Turkish military has historically shown itself to have sufficient freedom to make and change civilian allies in line with its self-perceived image of being above social dissensus, party politics, and particular interests. ${ }^{15}$ It first intervened, in 1960, with the backing of the secular, bureaucratic state party, the Republican People's Party (RPP), and state-centered intellectuals. However, the military's political allies narrowed during its second and third interventions, in 1971 and 1980, when only a small group of technocrats and politicians supported it.

The military positioned itself at a distance from the rest of society for several reasons. Most important, the army reproduced within itself its sentry role as an ideological task force prescribed by Kemalism, the official ideology of the state, named after the founder of the republic, Mustafa Kemal Atatürk. Kemalism as an ideology came to the fore in a series of general congresses of the RPP, beginning in 1927 and culminating in 1935, as a project of politically constructing and manipulating a modern Turkish nation-state on secular and western rather than Islamic precepts. It relied on the officer corps as the main carrier of these positivist-progressive ideals. Since then, the army has recruited itself from the sons 
of military personnel and civil servants in a way that has helped to perpetuate Kemalist commitments. ${ }^{16}$ More significantly, this recruitment pattern has also assured the military's place in the political system as the "guardians of the flame of Kemalism." 17 The broad mass of Turks, however respectful they may be of the founder, "do not really adhere to the army's Atatürk fetishism." 18 They adopt less militant and less expressive Kemalist ideals.

The Turkish military's self-perception that it is above political conflict also derives from its social autonomy. In the Ottoman Empire, the officer corps formed weak links with society through its special pattern of recruitment and by virtue of its membership in the political ruling class. Soldiers, the Janissaries, were selected from the Christian population, with those most distinguished in service being promoted to higher bureaucratic positions. This system of recruitment broke down by the eighteenth century, and until their destruction in 1826 the Janissaries formed links with society. The conditions that caused the isolation of the republican army from society, however, were produced by the vanguard role of the military and civilian bureaucracy. Because of this role, the military identified itself completely with the state and the status quo. A rift subsequently developed with the political elite, the civilian society's organized political expression. ${ }^{19}$

Generally, explanations of the military's aloofness from society rest on a sharp dichotomy between the prostate military and the less Kemalist, more traditional outlook of the masses. There are, however, reasons to contend that the conventional portrayal of Ottoman-Turkish political life in terms of a sharp dissensus between the civilian-military bureaucrats and the political elites was more apparent than real. Since the beginning of the multiparty period in 1946, the organized forces representing the civil society, rather than challenging the exemption of the military from civilian political control within constitutional democratic standards and norms, have managed to sustain a double discourse. ${ }^{20} \mathrm{On}$ the one hand, they have followed a conciliatory policy toward the military aimed at placating it; on the other, by giving prominence to the concept of "popular will" they have made only feeble efforts to relegate the military to a politically subordinate position in the system. Süleyman Demirel, the leader of the Justice Party (JP), the dominant party of the center-right during the 1960s, is one example. As prime minister, he established a political consensus with the military, which in the aftermath of the first military intervention in 1960 was more involved in politics than ever. "When he became Prime Minister [in 1965] he gave up all attempts to bring the military under civilian control and opted for virtual autonomy for the armed forces, leaving their administration to the commanders." 21 The present government's complete consensus with the military represents yet another extreme instance of the unwillingness of civilian forces to arouse the antagonism of the military. This double discourse strategy, to the extent that it is based on a pragmatic acknowledgment of the status quo, is basically defeatist in nature. It also fails to 
contribute to the long-term goal of establishing a more democratic model for civil-military relations.

The political complexities and dislocations caused by a less state-centered and more liberal political and economic development in the multiparty period since 1946 highlight a peculiar politicization of the military. In fact, ever since the inception of the republic the military has tended to be politicized in an antipolitical, rather than above-political, direction. The institutional separation of the military from politics in the early republic was not intended to establish civilian supremacy as in western Europe and America. ${ }^{22}$ Its only aim was to preclude the military's growth potential as a rival source of power to the ruling group. ${ }^{23}$ Therefore, in the course of Turkish political development it was necessary for the military to constitute a political front which claimed to be antipolitical. In this capacity it has been able to confront reactionary Islam, ethnic secessionism, and, with the emergence of left-wing ideologies, Communism. Political power throughout the republic has always resided in the barrel of a gun, although to differing degrees at different junctures.

Historically, then, not the Turkish military's attitude and discourse, but its strategic position/front within the political realm has determined the parameters of its political involvement. One such parameter has been the way the Turkish military has defined the essence of civilian political institutions and actors in antipolitical terms. ${ }^{24}$ The hallmarks of the civilian world, according to the military, are its praetorianism, instability, inefficacy, careerism, populism, lack of prudence, corruption, and irresponsibility. This antipolitical cognitive road map of the Turkish officer corps is incongruent with even the most flexible versions of the concept of democracy, let alone the most relevant definition of it in a nonwestern context as "a form of institutionalization of continual conflicts." 25 The military standards produce an impasse for the regime by conceiving the articulation and mediation of interests and resolution of conflicts by political parties and interest groups as disruptive. ${ }^{26}$ Democracy can take root only by the independent growth of the civil mechanisms of conflict management. It is therefore incompatible for a politically powerful military that conceives democracy as "a means of preserving and promoting the state" to promote a democratic impulse. ${ }^{27}$

\section{Indexes of Political Autonomy after 1980}

The expanded political autonomy of the Turkish military after 1980 resulted largely from the deep void in political authority during the political crisis before 1980.28 Turkey faced not only a regime crisis, manifested by the government's immobility in the face of increasing political violence, but also sharp unresolved tension between the civilian JP government and the military over the failure of martial law 
to end the bloodshed. ${ }^{29}$ While openly questioning the raison d'etre of the army as the guardian and guarantor of national security, the liberal to conservative spectrum of civilian politicians was not able to overcome its history of consensus with the military for fear of upsetting the political equilibrium. In line with the seriousness of the political crisis, the military's political autonomy became more pronounced and decisive after 1980 . The military became politically more powerful not because it was at the apex of its institutional achievements but because no other actor was capable of saving and restructuring the status quo. Another important source of the military's power was the lack of a tradition of pact making in Turkey that would enable a transition to democracy built on a broadly based national dialogue in which the rules for the democratic order could be set.

It is true that the military after 1980 operated under the old constraints of its ambivalence toward liberal democracy and the fundamental paradigm of the national security state. It is also correct to claim that the 1961 constitution and the 1973 constitutional amendments had already created a double-headed political system: the civilian council of ministers coexisted with the national security council on the executive level, and the military system of justice continued to operate independently alongside the civilian justice system. A new system of criminal courts, called the state security courts, was founded after $1980 .{ }^{30}$ Trying cases involving the security of the state, they were yet another blow to the principle of an independent judiciary because of the political manner in which the new courts' members were appointed.

National Security Council (NSC) In the last two decades the military has not only gained more strength vis-à-vis civilian actors, but by participating in the civilian authorities' decision-making process has also begun to extend its authority over areas that were traditionally under civilian control. Since military authority has been extended through constitutional/legal channels, some have interpreted it optimistically as a division of responsibilities with civilians to develop a more harmonious cooperation than existed before $1980 .{ }^{31}$ However, it is now apparent that the military has simply consolidated its political hegemony more deeply and made it unassailable. This new turn has been crystallized in and spearheaded by the national security council. Initially introduced by the 1961 constitution as an embodiment of the bureaucracy's primacy over the popularly elected parliament, it was designed to serve as a platform for the military to voice its opinion on matters of national security. Reflecting the more liberal outlook of 1960, civilian members exceeded senior commanders on it. ${ }^{32}$ With the 1973 amendments the primary function of the NSC was extended to making recommendations to the government. Finally, under the 1982 constitution its position was enhanced: its recommendations would be given priority consideration by the council of ministers. The 
number and weight of senior commanders participating in the NSC also increased at the expense of civilian members.

A close survey of the range and substance of decisions discussed or shaped in the NSC establishes beyond doubt that in the last two decades it has been the most decisive leg of a dual system of executive decision making, the other leg being the council of ministers. The concrete decisions of the council cover an unprecedented spectrum: determining the curriculum in schools; regulating television stations' broadcasting hours; abolishing the penal immunity of members of parliament from the (Kurdish) Democracy Party; closing down certain prisons and television stations; making bureaucratic appointments of the ministry of public works in the southeast; postponing the termination date of military service for current conscripts; suggesting the formation of electoral alignments between political parties before the March 27, 1994, local election; stating the substance of the laws on terror and capital punishment; and offering Arabic as an elective subject in secondary schools. ${ }^{33}$

The Presidency One crucial way the NSC has claimed further areas of executive power and state action has been through the presidential office's extended powers under the 1982 constitution. Augmenting the power of the presidency rested on a double assumption held by the military: in line with the republican tradition, either Turkish presidents would continue to be former generals, or, if civilians were elected, they would not be permitted to override the military. Developments after the election of the second civilian president, Turgut Özal, in 1989 and the third, Süleyman Demirel, in 1993 confirmed the soundness of these assumptions. ${ }^{34}$ Despite Özal's rather inflated image as a challenger of the military's political power and his seeming success in imposing the civilian government's choice for the general chief of staff in 1987, he could not have acted in this manner had he not procured the support of President Kenan Evren, the ex-general and leader of the coup. Nor did he attempt to change the military's legal framework, which would have been the institutional prerequisite to subject the military to civilian control. Former general chief of staff Necip Torumtay comments in his memoirs that Özal was not specifically committed to subjugating the military high command to civil authority, but rather totally disregarded any source of power in policymaking other than his own, civilians included. ${ }^{35}$

The current and third civilian president of the republic, Suileyman Demirel, is a seasoned political leader who since 1964 has faced two coups and political bans. It would be quite correct to note that he has basically remained a conservative politician more prone to strategic compromise with the military than any of his predecessors. ${ }^{36}$ His whole career has been based on an extremely skilful management of the political equilibrium of the status quo.

Organization of Defense The Turkish army's pervasive influence throughout the 
political system is also exercised through the organization of its relations to the government. Internationally, "executives prefer bureaucratic layers between themselves and the officer corps . . . they also prefer their authority to be centralized in a single, civilian-directed defense ministry, as opposed to separate military-supervised army, air force, and navy ministries. Where civilians control a single defense ministry, military autonomy is lowest." ${ }^{37}$ Although Turkey has such a single ministry of defense, rather than separate branch ministries, it is not quite correct to assume that it established full civilian control over the military.

The position of the Turkish general chief of staff has gone through three stages. In 1924 it was subjected to the prime minister; in 1949 it was placed under the control of the minister of defense; and under the 1961 constitution it once again became the prime minister's responsibility. That this position is above the minister of defense and other elected officials is confirmed by the general's manner of appointment and his duties. The general chief of staff is appointed by the president from the generals who were formerly commanders of the land forces, upon nomination by the council of ministers. ${ }^{38}$ In time of war, also under the 1982 constitution, the general chief of staff exercises the duties of commander-in-chief on behalf of the president of the republic.

Two separate laws passed in 1970 specified the duties of the minister of defense and general chief of staff. The general chief of staff obtained autonomy in determining defense policy, the military budget, future weapons systems, production and procurement of arms, intelligence gathering, internal security, and all promotions. In an interview with a foreign journalist in 1986, the then minister of defense confirmed the superior position and power of the general chief of staff succinctly: "The Turkish general chief of staff establishes the priorities and presents the requirements and needs" so that "tasks are carried out by the Ministry of Defense according to the principles, priorities and major programs as determined by the general chief of staff." ${ }^{39}$ In brief, it is possible to say that the function of the general chief of staff is to plan military policy and undertake the functions of command. ${ }^{40}$

The ability of the general chief of staff to influence the civilian bureaucracy in Turkey is facilitated by the lack of career civil servants specializing in military affairs who could provide a buffer between the military and society. ${ }^{41}$ This deficiency was pointed out by the minister of defense, Ahmet Topaloğlu, at the time the two acts in 1970 were passed. "In the Ministry of Defense, I am the only civilian person ... the undersecretary is a general. . . . We have not really set up a separate civilian organization. In many countries similar functions (military budget etc.) are entirely in the hands of a civilian technical cadre." ${ }^{2}$

Military Budgets If "actual annual disbursement of defense funds and military allotments as a percentage of central government expenditures provides a measure 


\section{Comparative Politics January 1997}

of military autonomy," it follows from the above analysis that the Turkish armed forces are particularly well-placed to press their demands for and to spend budgetary defense allocations. ${ }^{43}$ In contrast to the parliamentary micromanagement in many western democracies that prescribes in detail how the military should spend its budget, in Turkey "the defense budget has never been subjected to parliamentary debate. It has not been discussed in the press. It has never been criticized. Civilians have always said to themselves: "why should I be interested in the military; I had better try to please them.' "44 Yet another commentator points to the implications this secrecy has for the researcher studying the military. "We discuss everything. We keep track of most public expenditure. But we know nothing about the army. Nothing about defense is put on the agenda. We can not make use of domestic sources [on the military]. Thus, I used a foreign source: NATO's Comparison of Defense Expenditure, NATO Countries 1992." 45 With the additional effect of the struggle against the Kurdish PKK, the air of urgency and secrecy surrounding military expenditure has escalated, and the degree of public accountability has declined. In brief, unless it originates from the military, a reduction in defense expenditures and in the size of the armed forces is not likely.

Arms Production, Procurement, and Military Modernization It is claimed that autonomy is higher where defense industries remain in the hands of the armed forces, rather than partially controlled by the state or society, and "where the military can procure all the weapons systems it desires, . . . where civilians are unable to influence the reform process." 46

The primary reason for setting up a defense industry in Turkey was to lower the degree of dependence on allies for arms and technology. Production and procurement essentially comply with the priority list prepared by the general chief of staff and are considered to be in the military's own domain. The Turkish military-industrial complex is supported by a fund set up by the armed forces and managed by a civilian undersecretary in the ministry of defense ${ }^{47} \mathrm{In}$ addition to producing weapons systems, another objective of the undersecretariat is to achieve the modernization of the armed forces. The program to upgrade the efficiency of the forces' combat techniques, usually referred to in the press by the misnomer "professional army," was accelerated by the general chief of staff in the face of the combat forces' overt failure in the southeast against the PKK guerrillas. ${ }^{48}$ Although the modernization project has been underway since the 1970s, the senior hierarchy of the armed forces gave it an extra impetus in the late 1980s to enhance its credibility and legitimacy and to strengthen its political autonomy. ${ }^{49}$

Internal Security and Intelligence Gathering As in most other Third World countries, the Turkish military combines external defense with an internal security function. Throughout the republic it has repressed subversive political activity, 
Communism in the past and the PKK and, to a lesser extent, radical Islamists presently. Article 35 of the military's internal rules embodies the notion of internal enemies and legitimizes the basis for military interventions into politics. The recently retired former general chief of staff, Doğan Güreş, confirmed the still operative concept of internal security. "The duty of the Turkish armed forces has not changed. As in the past, it is to protect the Turkish republic against internal and external enemies." 50

In addition to the military's own intelligence operation units, the National Intelligence Agency of Turkey (NIA) serves as the civilian-based intelligence center subject to prime ministerial control. Despite its civilian character, the head and key cadres of NIA have always been recruited from officers and generals, either retired or active. Although the NIA is not nearly as powerful as the Brazilian security organizations, which acquired so much autonomy that they became a state within a state, elected officials and parliament have not established effective control over its policies and operations, supposedly on account of its sensitive nature. ${ }^{51}$ Only in 1992 was a career diplomat finally appointed as its head, giving rise to hopes that in the distant future some degree of civilian supervision might be exerted over the NIA.

Senior Promotions Civilian attempts to reduce the military's institutional autonomy in deciding senior promotions are in part intended to subject the military to constitutional authority. More important, they are also aimed at blocking the almost automatic succession of the chiefs of general staff to the presidency. The appointment of the forces' commanders and the general chief of staff thus has additional political importance. It was earlier pointed out that the president officially has the final say on whether to accept or reject the nominee for the general chief of staff. However, it is well-known that the incumbent chief of staff, in consultation with a number of senior commanders, selects his own successor, whom he suggests to the prime minister. The latter then forwards this "suggestion" to the president, in line with a vaguely defined and self-interpreted principle of seniority. Similarly, the general chief of staff, rather than the minister of defense, has the final say on who fills the positions of force commanders, apparently due to the same principle of seniority.

Three attempts were made in the 1970s to break the military's tradition of controlling senior promotions. In 1973, at a time of intense politicization and disunity within the army, an interparty alliance in parliament successfully prevented the election to the presidency of the hastily retired general chief of staff. 52 In 1976 and 1977 the prime minister, Süleyman Demirel, attempted to supersede the military's monopoly in deciding on the promotions for the force commanders' positions. The first effort was overruled by the supreme military 
administrative court, while the second was rejected by the president, a former admiral.

As mentioned earlier, in 1987 Prime Minister Turgut Özal seemingly succeeded in undermining the established tradition of routine senior promotions within the army by promoting General Necip Torumtay to the position of the general chief of staff, instead of the candidate favored by the incumbent. Commenting on his decision, Özal said: "Since 1960, no civilian government has appointed the general chief of staff itself. The position has been filled by automatic succession. From now on, this is going to be normalized. Governments should appoint the general chief of staff themselves according to merit." 53

However, as leader of the Motherland Party, itself a product of army intervention, Özal could not have had the final say if the president and leader of that last coup had not backed him fully. ${ }^{54}$ Indeed, in August 1993, immediately after taking office, the new Prime Minister Tansu Çiller endorsed the wish of the incumbent general chief of staff to extend his own term. Since then she has continued to opt for alignment with the military hierarchy in order to consolidate her political authority, proving that civilian rule continues to be vulnerable to the military. 55

\section{Conclusion}

The military autonomy of the period since 1980 represents a considerable shift in the military's influence, rather than a pattern of continuity. The pattern of politics established by the coup makers after 1980 was more authoritarian than ever before. Contrary to the previous constitution of 1961 , also the product of a coup, the 1982 constitution was designed by the military in line with the conservative logic of transition and restructured the Turkish polity by narrowing the bases of political participation and strengthening state institutions. It provided an ideal context for the expansion of military power vis-à-vis the three branches of government through legal-constitutional channels. The military's claim that the 1980 coup saved Turkey's political democracy from civil war also bolstered its increased power. This claim was made in a military culture and a society that legitimized the military's historical mission and institutional political role as the guardian of the state, and it supported a new pattern of increased military influence.

In Turkey, as elsewhere, any serious effort to promote liberal democracy must strengthen the accountability and legitimacy of civilian democratic forces. Limiting the power of the military is not an easy task. Legal-constitutional changes are necessary but not sufficient. The major factor contributing to the difficulty in establishing civilian control over the military is the failure of the civilian forces to question the prevailing power configuration. Therefore, the task of promoting 
liberal democracy requires above all a rethinking of the legacies governing the proper function and role of the armed forces across the entire spectrum of society. Only when a democratic and legitimate civilian-military relationship is established can political decision making, the power and status of representative institutions, the style of leadership, and the ways of exercising political power become more democratic.

\section{NOTES}

1. This essay will draw on the analysis of autonomy in David Pion-Berlin, "Military Autonomy and Emerging Democracies in South America," Comparative Politics, 25 (October 1992), 83-102.

2. Ibid., p. 85 .

3. Ibid.

4. Samuel Huntington, The Soldier and the State: The Theory and Politics of Civil-Military Relations (Cambridge: Harvard University Press, 1957), p. 74, claims that the military obeys civilian authorities when it has institutional autonomy characterized by high professionalism. Alfred Stepan challenged this assumption and argued that the military's increasing professionalism in the Third World under cold war conditions paved the way for its political role. Alfred Stepan, "The New Professionalism of Internal Warfare and Military Role Expansion," in Alfred Stepan, ed., Authoritarian Brazil: Origins, Policies and Future (New Haven: Yale University Press, 1973).

5. Elizabeth Pickard, "Arab Military in Politics: From Revolutionary Plot to Authoritarian State," in Adeed Dawisha and I. William Zartman, eds., Beyond Coercion and Durability (London: Croom Helm, 1988), p. 121; Karen Remmer, "The Politics of Military Rule in Chile, 1973-1987," Comparative Politics, 21 (January 1989), 152-56.

6. Nicole Ball, “The Military in Politics: Who Benefits and How?," World Development, 9 (1981), 575 .

7. Pion-Berlin, p. 85 .

8. Ibid.

9. Robert Pinkney, Right-Wing Military Government (London: Pinter, 1990), p. 98.

10. Ibid.

11. Henry Bienen and David Morell, "Transition from Military Rule: Thailand's Experience," in Catherine McArdle Kelleher, ed., Political-Military Systems (Beverly Hills: Sage, 1974), pp. 3-26.

12. See George Harris, "The Role of the Military in Turkey in the 1980s: Guardians or Decision-Makers," in Metin Heper and Ahmet Evin, eds., State, Democracy and the Military in Turkey in the 1980s (Berlin: De Gruyter, 1988), pp. 177-200.

13. See John J. Johnson, ed., The Role of the Military in Underdeveloped Countries (Princeton: Princeton University Press, 1962); Jose Nun, "The Middle Class Military Coup," in Claudio Veliz, ed., The Politics of Conformity (New York: Oxford University Press, 1967); Ergun Özbudun, The Role of the Turkish Military in Recent Turkish Politics (Cambridge, Mass.: Center for International Affairs, Harvard University, 1966); Hikmet Özdemir, Rejim ve Asker [The Regime and the Soldier] (Istanbul: Afa Yayincilik, 1989); Feroz Ahmad, "Military Intervention and the Crisis in Turkey," in Hüseyin Ramazanoglu, ed., Turkey in the World Capitalist System (Hong Kong: Avebury, 1985), pp. 193-94.

14. Sungur Savran, "Türkiye'de Darbeler" [Coups in Turkey], 11. Tez, 6 (1986), 132-68.

15. Alfred Stepan, The Military in Politics: The Changing Patterns in Brazil (Princeton: Princeton University Press, 1971), p. 270.

16. James Brown, "The Military and Society: The Turkish Case," Middle Eastern Studies, 25 (July 1989), 399. 


\section{Comparative Politics January 1997}

17. Ibid.

18. Ahmet Kemal, "Military Rule and the Future of Democracy in Turkey," Middle East Report, 122 (March-April 1984), 13.

19. Metin Heper, "Introduction," in Metin Heper and Jacob Landau, eds., Political Parties and Democracy in Turkey (London: I. B. Tauris, 1991), pp. 7-12.

20. Ümit Cizre Sakallioğlu, Adalet Partisi-Ordu Ilişkileri: Bir Ikilemin Anatomisi [The Relations between the Justice Party and the Military: The Anatomy of a Dilemma] (Ankara: Iletişim Yayinlari, 1993).

21. Feroz Ahmad, The Turkish Experiment in Democracy 1950-1975 (London: C. Hurst, 1977), p. 237.

22. The ministries of shari'a and of chief-of-staff were abolished and reduced to government departments in 1924 on the grounds that "for religion and the military to be interested in politics leads to various negative results." Quoted from M. Kemal Atatürk in Mahmut Goloğlu, Devrimler ve Tepkileri 1924-1930 [Reforms and Reactions 1924-1930] (Ankara: Başvur Matbaasi, 1972), p. 9.

23. See Dankwart A. Rustow, "The Army and the Founding of the Turkish Republic," World Politics, 4 (July 1959), 549; Daniel Lerner and Richard O. Robinson, "Swords and Ploughshares: The Turkish Army as a Modernizing Force," World Politics, 13 (1960-1961), 22; William Hale, "Transitions to Civilian Governments in Turkey: The Military Perspective," in Heper and Evin, eds., State, Democracy and the Military, p. 174.

24. See Mehmet Ali Birand, Emret Komutanim [Order, My Commander] (Ankara: Milliyet Yayinlari, 1986), pp. 114-54.

25. Adam Przeworski, "Problems in the Study of Transition to Democracy," in Guillermo O'Donnell et al., eds., Transitions from Authoritarian Rule: Comparative Perspectives (Baltimore: The Johns Hopkins University Press, 1986), p. 58.

26. Ali Karaosmanoğlu, "Officers: Westernization and Democracy," in Metin Heper et al., eds., Turkey and the West: Changing Political and Cultural Identities (London: I. B. Tauris, 1993), pp. 24-29.

27. Ibid., p. 24.

28. For an analysis of the period before 1980 as "praetorian" and "syndicalist," see John $\mathbf{H}$. McFadden, "Civil-Military Relations in the Third Turkish Republic," The Middle East Journal, 39 (Winter 1989), 69.

29. See Sakallioğlu, pp. 239-63.

30. The system of state security courts was included in the 1973 amendments to the 1961 constitution. Until it was set up after the 1980 intervention, it was strongly opposed by the opposition Republican People's Party on the grounds that these courts violated the principle of judiciary independence and were antidemocratic. The constitutional amendment was nullified by the constitutional court in 1975 . 31. Harris, p. 199.

32. Along with the general chief of staff and the three force commanders, it consisted of the prime minister and a number of ministers. Depending on the situation, some of these ministers were specified, while others were left to the prime minister's discretion.

33. For a group of representative articles by well-known journalists and writers on the focal position of the NSC, see Ertuğrul Özkök, "Milli Güvenlik Kurulu Gündemde” [National Security Council Is on the Agenda], Hürriyet (Istanbul daily), Nov. 30, 1991; Fatih Çekirge, "Genelkurmay'in Ilginç Önerisi” [The General Staff's Interesting Sugestion], Sabah (Istanbul daily), Nov. 16, 1993; Sedat Ergin, "Çiller ve Ordu-Hükümet Ilişkisi" [Çiller and the Military-Government Relations], Hürriyet, Nov. 30, 1993; Cengiz Çandar, "Türkiye'yi Kim Yönetiyor?” [Who Rules Turkey?], Sabah, Jan. 8, 1994; Mehmet Altan, "Askeri Analyiş, Demokratik Analyiş" [Military Understanding, Democratic Understanding], Sabah, Jan. 10, 1994; M. Ali Birand, "Çok Şükür, Bu Da Oldu!" [Thank God This Happened, Too!], Sabah, Jan. 30, 1994. 
34. The term of the first civilian president, Celal Bayar (1950-1960), was terminated by the first coup in 1960

35. Necip Torumtay, Orgeneral Torumtay'in Anilari [The Memoirs of Army Commander Torumtay] (Istanbul: Milliyet Yayinlari, 1993), pp. 107-30.

36. For an instance of Demirel's politics of balancing after 1980, while in opposition he said that "the position of the general chief of staff should be under the minister of defense . . . a reorganization is a must." Milliyet (an Istanbul daily), May 28, 1990. Two years later as the prime minister he arranged for the bill placing the general chief of staff under the minister of defense to be defeated by the votes of his party members in the parliamentary defense commission on May 14, 1992.

37. Pion-Berlin, "Military Autonomy," p. 89.

38. Although the 1961 and 1982 constitutions both inscribe "land, naval or air forces," by an unwritten code all the chiefs of general staff are drawn from the land forces.

39. NATO's 16 Nations: Special Issue, Defense and Economics in Turkey, 31 (1986), 66, 69.

40. Özdemir, p. 144

41. The creation of a parliamentary commission in 1991 with the assignment, among other objectives, to civilianize the ministry of defense attests to the domination of the ministry's present staff by career officers. Günes (Istanbul daily), Feb. 10, 1991.

42. Quoted in Özdemir, p. 255.

43. Pion-Berlin, p. 88.

44. M. Ali Birand, Nokta (Istanbul weekly), Nov. 2, 1986.

45. Ali Riza Kardüz, "Asker mi Az, Para mi Az?" [What Is in Shortage, Soldiers or Money?], Sabah, Nov. 29, 1993.

46. Pion-Berlin, pp. 88-89.

47. Originally founded as the directorate for the support and development of defense industries in 1985, it was later turned into the undersecretariat for defense industries. The defense industry support fund was established in 1986 to finance the armed forces' ten year, $\$ 10$ billion modernization plan and to create a national defense industry.

48. See the interview with the former commander of the land forces, General Necdet Öztorun, "Amaç Caydiricilik" [The Purpose Is Deterrence], Nokta, Nov. 13, 1988; "PKK"ya Karşi Yeni Strateji" [A New Strategy against the PKK], Hürrivet, Nov. 2, 1991; Yalçin Doğan, "Güney Doğu'da Tarihsel Karar" [The Historic Decision in the Southeast], Milliyet, Nov. 2, 1991.

49. See "Ordu Rahatsiz" [The Army Is Restless], Hürriyet, Aug. 20, 1989. The grandest project of the Turkish military-industrial complex is the production of F-16 fighter jets in Turkey, under license. It began in 1987 under the financial responsibility and coordination of the undersecretariat for defense industries.

50. Hürriyet, Jan. 21, 1992.

51. See Alfred Stepan, Rethinking Military Politics: Brazil and the Southern Cone (Princeton: Princeton University Press, 1988).

52. See Muhsin Batur, Anilar ve Görüşler [Memoirs and Perspectives] (Istanbul: Milliyet Yayinlari, 1985), pp. 360-73, 430. The general was Faruk Gürler, who as the land forces commander had been a signatory of the ultimatum given to the JP government. See Roger P. Nye, "Civilian-Military Confrontation in Turkey: The 1973 Presidential Election," International Journal of Middle Eastern Studies, 8 (1977), 209-23.

53. Ertuğrul Özkök, "Özal Anlatiyor" [Özal Explains], Hürrivet, Apr. 20, 1993. It should be noted that, according to one former MP cabinet minister and leading policymaker in the party, Güneş Taner, the chief reason why General Necdet Öztorun was not favored by the prime minister was his arrogant attitude toward the civilian political hierarchy as perceived by the MP leadership cadres. See "Güneş Taner'e Göre Öztorun Olayi Bir Darbeye Dayanabilirdi" [According to Güneş Taner, the Öztorun Incident Could Have Led to a Coup], Hürrivet, July 14, 1995. 


\section{Comparative Politics January 1997}

54. According to one source, Kenan Evren and the four members of the national security council, who had acted as the executive council after the 1980 coup for three years, engineered the 1987 incident. The incident resulted from the persistent splits within the army provoked by the 1980 coup. Interview with retired general Yilmaz Doğrusöz, Ekonomi Politika (Istanbul weekly), Aug. 8-15, 1993.

55. Çiller seemingly based her choice on the logic that the military strategy should not be disrupted by a change at the highest command in the ongoing guerrilla war in the southeast. 